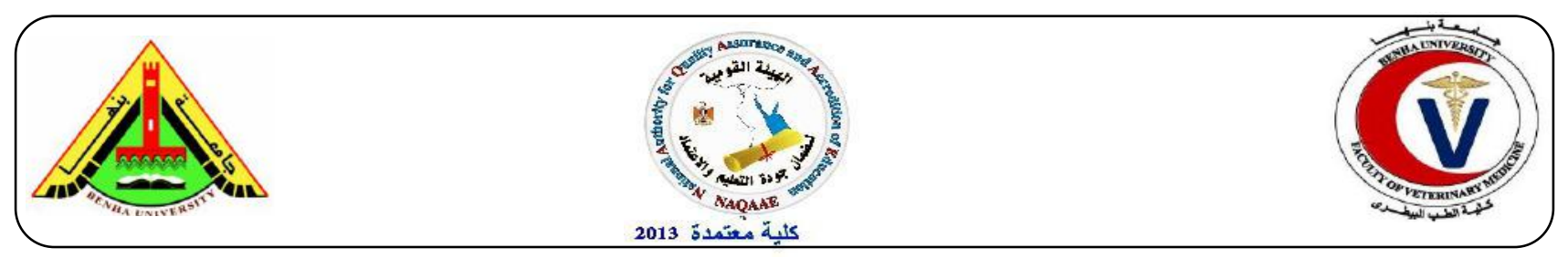

\title{
Histomorphometry of Dromedary Camel Epididymis and its Correlation with Spermatozoa Characteristics during their Epididymal Transport
}

\author{
Rashad, D.E.M ${ }^{1}$, Kandiel, M.M.M. ${ }^{1}$, Agag, M.A. ${ }^{1}$, El-Khawagah, A.R.M. ${ }^{1}$, Karima, Gh.M. \\ Mahmoud $^{2}$, Ahmed, Y.F. ${ }^{2}$, Abou El-Roos, M.E.A. ${ }^{1}$, Sosa, G.A.M. ${ }^{1}$ \\ ${ }^{1}$ Theriogenology Department, Faculty Veterinary Medicine, Benha University \\ ${ }^{2}$ Animal Reproduction and Artificial Insemination, National Research Centre, Dokki, Giza.
}

\section{A B S T R A C T}

This study aimed to assess the relation between the morphometric and histological attributes of the epididymis, and epididymal semen features in mature dromedary camels. The testes with the attached epididymis $(n=50)$ were collected from adult camels along the rutting season from December to April. The separated epididymis was evaluated for weight and length prior to the dissection. Samples from each epididymal segment were processed for histomorphometric examination. Epithelial height, luminal diameter, tubular diameter, stereocilia height, muscular coat thickness and histogram of the intra luminal content were measured. The harvested epididymal semen was evaluated for motility, concentration and livability. The intra-luminal cellular contents (histogram in pixels), epithelial and stereocilia heights, and muscular coat thickness were maximal in the epididymal head. The epididymal tail showed wider luminal and tubular diameters than head and body. The tubular diameter and histogram were positively correlated $(p<0.05)$ with sperm motility in the head and body segments. The length of head epididymal segment was negatively correlated with sperm concentration. Epithelial height, stereocilia height were negatively correlated with sperm motility in epididymal body. In conclusion, the histomorphometry aspects of the epididymis eminently impacts spermatozoa features in dromedary camel.

Keywords: Camel, Epididymis, Histomorphometry, Rutting season, Spermatozoa

(http://www.bvmj.bu.edu.eg)

(BVMJ-35(1): 1-11, 2018)

\section{INTRODUCTION}

Maintenance of high levels of reproduction in camel is crucial, not only for profitable production, but also for providing ample opportunities for the selection and genetic improvement of this important species (Mostafa et al., 2014).

The epididymis is a highly important dynamic organ that acts as a reservoir for spermatozoa, beside controls the maturation and fertility of sperm cells (Senger, 2006). In camels, the epididymis is distinguished anatomically into head, body and tail (Nickel et al., 1979). The head of epididymis (caput) is curved around the cranial testicular pole and attached to the apical extremity of the testis by a fibrous band (Zayed et al., 2012). The epididymal body (corpus) is attached to the dorsal testicular border forming a sinus opens laterally (Zayed et al., 2012). The epididymal tail (cauda) is attached to the 
distal testicular extremity by the proper ligament of the testis and attached to the tunica vaginalis by the ligament of the tail of the epididymis (Zayed et al., 2012).

The camel epididymal spermatozoa are able to preserve their ability to fertilize mature oocytes in vitro, because they are easy to be capacitated than the ejaculated spermatozoa (Scholkamy et al., 2016). Those oocytes inseminated with dromedaries epididymal semen show statistically similar penetration, fertilization and first cleavage rates (Badr and Abdel-Malak, 2010).

There are two important sperm features related to its fertilizing power are achieved during epididymal passage; motility and chromatin stability (Rodríguez and Bustos-Obergón, 1994). While spermatozoa release from the rete testis to the end of the epididymis, many physicochemical changes are happened (Pineda, 1989). These include morphological, functional and maturational modifications (Bedford, 1975; Olson, 1984) to be able to withstand the storage without losing their fertility potential (Bishop and Walton, 1960). The signal of sperm cell maturation process is the shift in the position and shape of the cytoplasmic droplet. In contrast with other domestic species, epididymal spermatozoa of dromedary camels are characterized by a high number of morphologically abnormal epididymal spermatozoa, slow cytoplasmic droplet migration and high rate of spermatozoa cytoplasmic droplet in the epididymal tail. (Osman and Plöen, 1986).

The current study was designed to evaluate the relation between the macroscopic and microscopic morphometric characteristics of the epididymis, and epididymal semen features in mature dromedary camels during the rutting season.

\section{MATERIAL AND METHODS}

Epididymis semen collection and evaluation
Testes and epididymis $(\mathrm{n}=50)$ were collected from apparently healthy slaughtered camels aged 5 to 10 years during the rutting season (December - April) at Toukh abattoir, Qalyubia governorate. At the laboratory, the epididymis was dissected and separated from the testis, according to $\mathrm{Yu}$ and Leibo (2002), rinsed with $0.9 \%$ saline and its weight $(\mathrm{g})$ and length $(\mathrm{cm})$ were recorded as described by Mahmud et al. (2015). Each epididymis was distinguished into head, body and tail as described by Zayed et al. (2012), incised and the leaked semen was examined for the motility (Melo et al., 2005), concentration (Atiq et al., 2011) and livability (EL-Sisy et al., 2008).

\section{Histomorphological examination}

Epididymal samples were prepared and stained as described by Drury and Wallington (1976). Briefly, small tissue samples from each epididymal segments were fixed in $10 \%$ neutral buffered formalin and dehydrated through graded concentrations of ethanol before being embedded in paraffin wax. Serial paraffin sections $(5 \mu \mathrm{m})$ were prepared and stained with Haematoxylin and Eosin (H\&E). The epididymal histomorphological features were evaluated according to the procedure of Beguelini et al. (2010). Briefly, the epithelial height was taken as the linear length of the principal cells, from the base of the epithelium (basal lamina) to the apical edge (excluding the stereocilia). The luminal diameter was taken as the longest measurement from one apical edge to the other The tubular diameter was taken as the longest distance between basal basal laminas. The height of stereocilia, muscular coat thickness and histogram of the intra luminal content were evaluated by using Image $\mathbf{J}$ (Java based image processing program developed by National Institutes of Health, USA and free available at (https://imagej.nih.gov/ij/index.). Also, tissue 
samples were taken from each epididymal segments, fixed in paraformaldehydegluteraraldehyde solution in phosphate buffer (Karnovsky 1965), post fixed in 1\% osmium tetraoxide for one hour. Then washed in 0.1 M phosphate buffer $(7.3 \mathrm{pH})$, dehydrated in graded ethanol and embedded in epon-araldite mixture (Mollenhauer, 1964). Then semithin sections $(1 \mu \mathrm{m})$ were cutted, stained with toluidine blue (Richardson et al., 1960) and examined microscopically.

\section{Statistical analysis}

The data were presented as mean \pm standard error of means (SEM). The differences between epididymal segments measures were statistically analyzed with one way ANOVA, and Duncan post-hoc test. Pearson correlation coefficient was used to testify the correlation between epididymal morphometric parameters and semen features. All statistical analyses were achieved with IBM-SPSS for Windows (Ver. 23) statistical software. The differences were considered to be significant at $\mathrm{P}<0.05$ (SPSS, 2017).

\section{RESULTS}

Morphometric and histological characteristics of dromedary camels' epididymis

Figure 1 illustrates intact and excised dromedary camel epididymis. The weight, length and their equivalent ratio from the whole organ varied significantly $(p<0.001)$ between epididymal segments, as the epididymal head was the heaviest and longest part (Table 1).

The luminal and tubular diameters of epididymal tail were considerably $(\mathrm{p}<0.001)$ wider than that of the body and head segments. The stereocilia and epithelial heights as well as muscular coat thickness of epididymal head were significantly $(\mathrm{p}<0.001$, 0.05 , and 0.05 , respectively) higher than that of the body and tail segments. The epididymal intra-luminal spermatozoa contents in the head region, indicated by the histogram (in pixels), was significantly $(\mathrm{p}<0.0001)$ higher than that of the tail and body segments (Table $1)$.
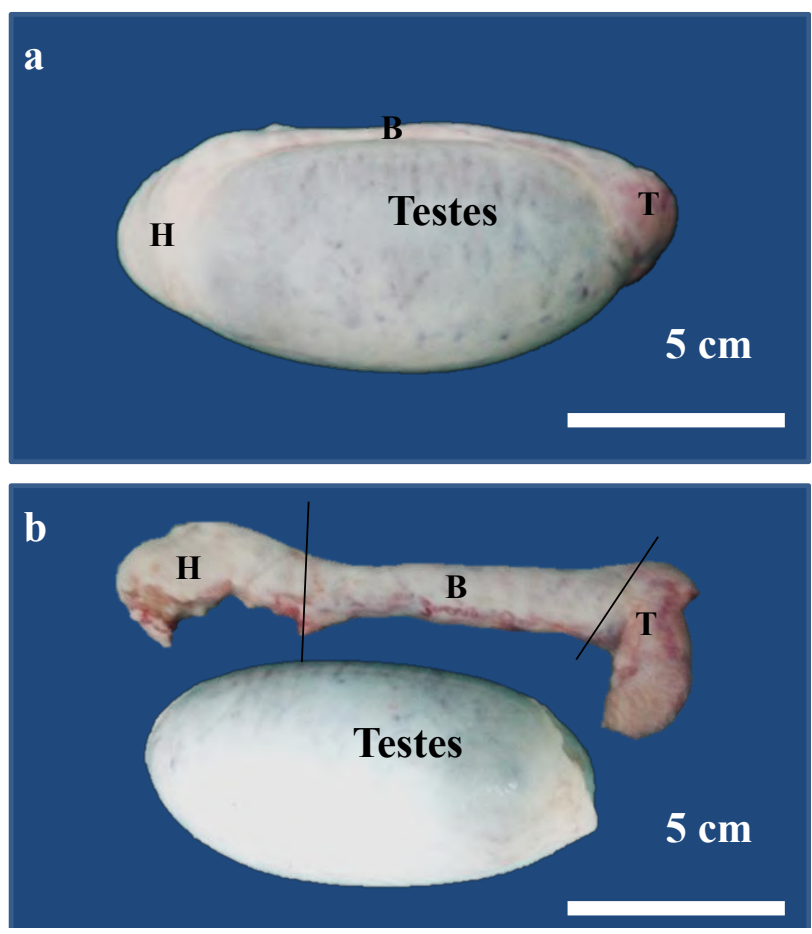

Figure 1 Dromedary camel testis and epididymis. a: The testis with attached epididymis. b: Dissected epididymis with demonstration of head (H), body (B) and tail (T) segments 
Table 1 Histomorphometry of camel epididymis

\begin{tabular}{|c|c|c|c|c|c|}
\hline \multirow{5}{*}{ 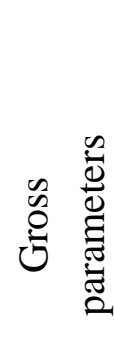 } & \multicolumn{2}{|l|}{ Item } & \multirow{2}{*}{$\frac{\text { Head }}{8.96 \pm 0.49^{\mathrm{a}}}$} & \multirow{2}{*}{$\begin{array}{c}\text { Body } \\
5.58 \pm 0.27^{b}\end{array}$} & \multirow{2}{*}{$\begin{array}{c}\text { Tail } \\
5.35 \pm 0.32^{\mathrm{b}}\end{array}$} \\
\hline & Weight & (g) & & & \\
\hline & & $(\%)$ & $43.41 \pm 1.32^{\mathrm{a}}$ & $27.88 \pm 1.19^{b}$ & $26.41 \pm 1.11^{\mathrm{b}}$ \\
\hline & Length & $(\mathrm{cm})$ & $10.09 \pm 0.51^{\mathrm{a}}$ & $5.95 \pm 0.35^{\mathrm{b}}$ & $6.12 \pm 0.46^{\mathrm{b}}$ \\
\hline & & $(\%)$ & $44.6 \pm 1.88^{\mathrm{a}}$ & $26.54 \pm 1.59^{b}$ & $27.33 \pm 1.68^{\mathrm{b}}$ \\
\hline 2 & Luminal & Im) & $195.96 \pm 9.88^{b}$ & $234 \pm 7.42^{b}$ & $511.63 \pm 58.20^{\mathrm{a}}$ \\
\hline है & Tubular & & $347.23 \pm 14.371^{\mathrm{b}}$ & $371.89 \pm 23.78^{b}$ & $656.85 \pm 61.84^{\mathrm{a}}$ \\
\hline 苛 & Epitheli & & $139.58 \pm 40.06^{\mathrm{a}}$ & $63.8056 \pm 6.53^{b}$ & $35.1 \pm 3.41^{\mathrm{b}}$ \\
\hline 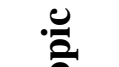 & Stereoci & m) & $27.1917 \pm 4.00^{\mathrm{a}}$ & $9.1406 \pm 0.60^{\mathrm{a}}$ & $4.5104 \pm 0.66^{\mathrm{b}}$ \\
\hline : & Muscula & ness $(\mu \mathrm{m})$ & $64.35 \pm 13.19^{\mathrm{a}}$ & $27.1429 \pm 1.84^{b}$ & $36.5795 \pm 5.58^{b}$ \\
\hline$\sum$ & Intra-lur & Ir contents & $165.8 \pm 7.7^{\mathrm{a}}$ & $118.2 \pm 10.2^{b}$ & $139.4 \pm 5.8^{\mathrm{ab}}$ \\
\hline
\end{tabular}

Values (mean \pm SE) of the same item with different superscripts $\left({ }^{\mathrm{a}, \mathrm{b}} \cdots\right)$ within the same column were significantly different at $p<0.05$.

Histologically, epididymal segments shared a communal architecture characterized by stereo-ciliated pseudo-stratified columnar epithelium lining, thin smooth muscular coat and an outer tunica serosa (Figure 2). The epididymal epithelium contained five different cell types (principal, basal, apical dark and halo cells) that showed dissimilar distribution among epididymal segments. The principal and basal cells were the unique most frequent cells in the whole epididymis. In the head segment, the measures of the stereocilia and epithelial height, and muscular coat thickness overcame its contemporaries in the body and tail of the epididymis. Besides, there was frequent apical, dark, halo cell. In body segment, the round nuclei in the lining epithelium were situated at high uneven level. In the tail segment, the dark stained nuclei of the principal cells in the lining epithelium were arranged evenly as a row above the level of basal cells. The apical cells were scarcely observed and the stereocilia were extremely short. 

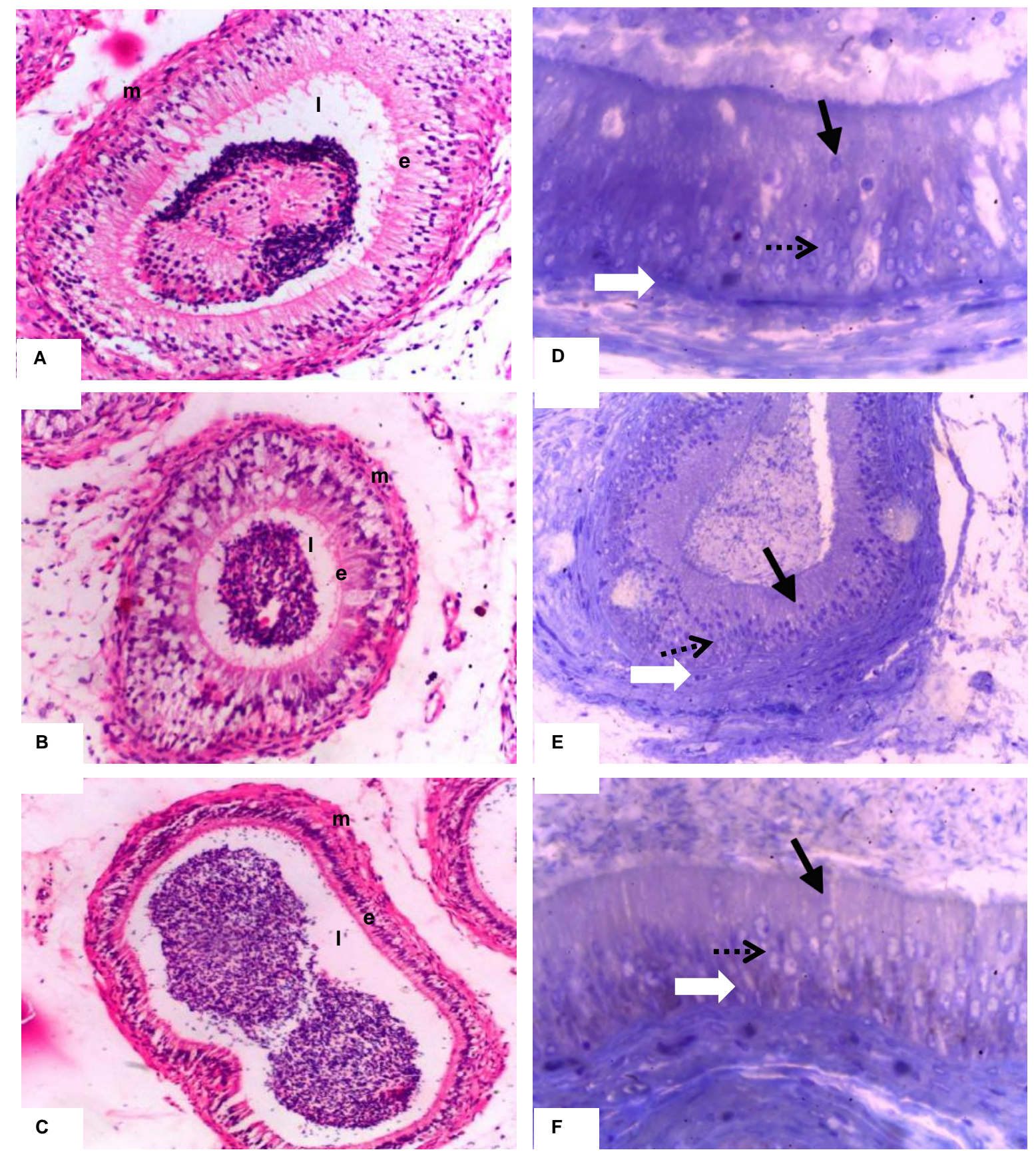

Figure 2 Histological architecture and ultra-structure of normal camel epididymis at the head (A \& D), body (B \& E) and tail ( C \& F) segments. A, B and C were stained by hematoxylin and eosin stain and photographed at $\times 200$. D, E and $\mathrm{F}$ were semi-thin sections stained by toluidine blue stain and photographed at $\times 1000$. e, 1 and $\mathrm{m}$ referred to epithelium layer, lumen and muscular coat. Solid $(\rightarrow)$, open $(\Rightarrow)$ and dashed $(\rightarrow)$ arrows referred to apical, basal and principle cells, respectively.

\section{Epididymal semen characteristics of camels and its correlations with epididymal morphometry}

Spermatozoa harvested from tail segment of camel epididymis characterized by the highest sperm motility $(58.13 \pm 2.82 \%)$, concentration $\left(224.70 \pm 24.86 \times 10^{6} / \mathrm{ml}\right)$ and livability $(50.05 \pm 2.97$ $\%$ ) as compared with the corresponding values of head and boy segments (Table 2). 
At the head segment, the sperm motility was significantly $(\mathrm{p}<0.05)$ positive correlated with tubular diameter $(\mathrm{r}=0.88)$ and intra-luminal content $(\mathrm{r}=0.82)$ but correlated negatively with stereocilia height $(\mathrm{p}=0.07, \mathrm{r}=0.77)$. The sperm concentration was significantly $(\mathrm{p}<0.05, \mathrm{r}=-0.89)$ negative correlated with epididymal head length (Table 3). At the body segment, there was significant positive correlations between sperm motility and lumen diameter, tubular diameter and intra-luminal cellular content ( $\mathrm{p}<0.01 ; \mathrm{r}=0.97, \mathrm{p}<0.05 ; \mathrm{r}=0.86$, and $\mathrm{p}<0.05 ; \mathrm{r}=0.91$, respectively). But, the sperm motility was significantly $(\mathrm{p}<0.01)$ negatively correlated with epithelial and stereocilia heights $(r=-0.95$ and -0.96 , respectively).

Table 2 Camel epididymal spermatozoa motility, count and livability

\begin{tabular}{lccc}
\hline Item & Head & Body & Tail \\
\hline Spermatozoa motility $(\%)$ & $13.33 \pm 2.25^{\mathrm{c}}$ & $39.17 \pm 1.68^{\mathrm{b}}$ & $58.13 \pm 2.82^{\mathrm{a}}$ \\
Sperm cell count $\left(\times 10^{6} / \mathrm{ml}\right)$ & $58.75 \pm 10.87^{\mathrm{b}}$ & $96.63 \pm 16.64^{\mathrm{b}}$ & $224.70 \pm 24.86^{\mathrm{a}}$ \\
Livability $(\%)$ & $17.16 \pm 1.35^{\mathrm{c}}$ & $26.35 \pm 1.58^{\mathrm{b}}$ & $50.05 \pm 2.97^{\mathrm{a}}$
\end{tabular}

Values (mean \pm SE) with different superscripts $\left({ }^{\mathrm{a}, \mathrm{b}}\right.$ ) within the same row were significantly different at $\mathrm{p}<0.05$.

Table 3 Correlation between morphometric characteristics of the epididymis and semen features in mature dromedary camel

\begin{tabular}{ll|cccccccc}
\hline $\begin{array}{l}\text { Epidid. } \\
\text { segment }\end{array}$ & $\begin{array}{l}\text { Semen } \\
\text { features }\end{array}$ & Wt. & L. & $\begin{array}{c}\text { Lumen } \\
\text { diam. }\end{array}$ & $\begin{array}{c}\text { Tub. } \\
\text { Diam. }\end{array}$ & $\begin{array}{c}\text { Epith. } \\
\text { height }\end{array}$ & $\begin{array}{c}\text { Stereoc. } \\
\text { height }\end{array}$ & $\begin{array}{c}\text { Muscul. } \\
\text { thick. }\end{array}$ & $\begin{array}{c}\text { luminal } \\
\text { content }\end{array}$ \\
\hline \multirow{2}{*}{ Head } & Motility & -0.10 & -0.46 & 0.72 & $0.88^{*}$ & -0.72 & -0.77 & 0.53 & $0.82^{*}$ \\
& Conc. & -0.68 & $-0.89^{*}$ & 0.10 & 0.56 & -0.51 & -0.64 & 0.38 & 0.73 \\
& Livability & -0.60 & 0.03 & -0.39 & -0.21 & 0.30 & 0.40 & -0.49 & -0.28 \\
\hline \multirow{2}{*}{ Body } & Motility & -0.50 & 0.69 & $0.97^{* *}$ & $0.86^{*}$ & $-0.95^{* *}$ & $-0.96^{* *}$ & 0.76 & $0.91^{*}$ \\
& Conc. & 0.28 & 0.09 & 0.15 & 0.30 & -0.15 & -0.11 & 0.20 & 0.22 \\
& Livability & -0.49 & -0.31 & 0.05 & 0.35 & 0.04 & 0.14 & -0.50 & -0.21 \\
\hline \multirow{2}{*}{ Tail } & Motility & -0.50 & 0.57 & 0.66 & 0.63 & -0.31 & -0.55 & 0.72 & 0.27 \\
& Conc. & -0.24 & 0.32 & 0.65 & 0.51 & -0.36 & -0.52 & 0.58 & 0.49 \\
& Livability & 0.68 & 0.55 & -0.23 & -0.33 & 0.41 & 0.36 & -0.15 & -0.48 \\
\hline
\end{tabular}

$*$ and $* *$ indicated significant correlation at $\mathrm{p}<0.05$ and 0.01 , respectively (2- tailed).

\section{DISCUSSION}

Camels are an important livestock species uniquely adapted to hot and arid environments. However, they are characterized by low reproductive and productive performances compared to other species. This need more attention for efficient reproduction in this species (Brown, 2000). Maintenance of high levels of reproduction in camel is essential for profitable production as well as genetic selection and improvement (Agag, 1991; Mostafa et al., 2014).

In the present study the weight of camel epididymal head, body and tail was 
$8.96 \pm 0.49, \quad 5.58 \pm 0.27$ and $5.35 \pm 0.32 \mathrm{~g}$, respectively and this was corresponding to $43.41 \pm 1.32 \%, 27.88 \pm 1.19 \%$ and $26.41 \pm 1.11 \%$ of the whole organ weight. These findings are close to those reported by Ibrahim et al. (2012), who mentioned that capute weighs larger than cauda and corpus. In the present work, the epididymal head was the heaviest and largest part of the epididymal segments. This finding strongly agreed with Ibrahim et al. (2012) in dromedary camel. This enlargement in epididymal head are due to the presence of efferent ducts that were received from the testes (Zayed et al., 2012). In former studies, the body (Skidmore, 2000) or tail (Mahmud et al., 2015) segments of the epididymis appeared the largest segment in one-humped camel. The differences between our results and the former reports might be attributed to the season of the year (Zayed et al., 2012; Ibrahim and Singh, 2014), area (Ibrahim and Singh, 2014) feeding regimen or animal age (Novoa, 1970; Arthur et al., 1985; Al-Qarawi et al., 2000). The seasonality greatly impacts the reproductive function of the epididymal duct in the camel with special emphasis to the weight and volume of the epididymis, and total diameter of the epididymal duct. El-Kon et al. (2011) indicated that the age of the dromedary camels and season of the year substantially impact testicular sperm production and testosterone levels.

The present study showed that epididymal duct of camel was lined internally by pseudo-stratified ciliated columnar epithelium which is gradually decline in height along the epididymal duct from the initial to the terminal segments. These findings mimic the previously mentioned observations in the camel (Axner et al., 1999; Alkafafy, 2005). Former study indicated that the gradual change in epithelial height smoothed the passage of the spermatozoa toward the terminal segment (Zayed et al., 2012). In this respect, Crabo (1965) mentioned that, over $90 \%$ of the bull testicular fluids entering the epididymis had been absorbed in the head region. Also, Turner (1984) reported that, the fluid removal is associated with a net resorption of sodium ions between the rete testis and the proximal segment of the epididymis. Former study reported that the lowered epithelial height in the epididymal tail could be attributed to luminal spermatozoa overcrowdings, while the epididymal head and body were thought to be involved in sperm maturation (Glover and Nicander, 1971). Moreover, the epididymal epithelium in the initial segment is provided with stereocilia which is long and branched in the head segment and decrease in length toward tail segment. These findings came in harmony with Axner et al. (1999), Junqueira and Carneiro (2003) and Zayed et al. (2012). The long well-developed stereocilia in the proximal epididymal segment increase the surface area and facilitate the movement of molecules into and out the cells (Martini et al., 2001; Junqueira and Carneiro, 2003). The differences in the stereocilia height between the epididymal head and tail may be attributed to the high absorptive and secretory functions of the epididymal head in comparison to the tail segment (Yamamoto and Turner, 1991). The demonstration of five types of cells, termed principal, basal, apical, dark and halo cells in the epithelium lining of the epididymal duct, imitate that published previously in the camel (Ebada, 1994; Zayed et al., 2012). In this study, the epididymal duct was seen lined by numerous layers of circular smooth muscle fibers which were thicker in the head than body and tail segments. The periductular smooth muscle coat along the whole epididymal length contributes in the sperm passage toward the terminal segment (Goyal, 1985; Ebada, 1994). 
The rhythmic peristaltic contractions in epdidymal head and body assist in conveying spermatozoa along the duct (Ross et al., 1989). The muscular coat in the tail segment may help in the process of ejaculation (Glover and Nicander, 1971). The histogram of the intraluminal sperm content in the head region observed in the current study designate the high cellular population consists of spermatozoa, phagocytes, leukocytes, and other types of cells. The phagocytic cells, of epididymal origin, help in engulfing of the immature, inactive, dead spermatozoa as well as phagocytosis of protoplasmic droplets (Sutovsky et al., 20・1).

At the head segment, the positive correlation between sperm motility and tubular diameter and intra-luminal content, as well as negative correlation between sperm motility with stereocilia height and negative correlation between sperm concentration and epididymal head length might verify that testicular spermatozoa were concentrated at initial epididymal segment, as it was mentioned in former study (Crabo, 1965). At the body segment, luminal and tubular diameters become wider, so allow easy spermatozoa movement toward the tail, and provide wide space for spermatozoa storage and this explain the positive correlation between sperm motility and tubular diameter and intra-luminal content.

\section{Conclusion}

The epididymal biometry and histological arrangements greatly varied between head, body and tail segments in mature camels. This essentially influenced its functions related to sperm features including motility, livability and concentration.

\section{REFERENCES}

Agag, M.A. (1991): Studies on the reproductive function of the male dromedary camel with special reference to age and season. Ph.D. Thesis, Faculty of Veterinary Medicine, Benha University.

Alkafafy, M., (2005): Glyco-histochemical, immune-histochemical and ultrastructural studies of the bovine epididymis. Ph.D. Thesis, Faculty of Veterinary Medicine, LudwigMaximillian Universität, München, Germany.

AL-Qarawi, A.A.; Abdel-Rahman, H.A.; ELBelely, M.S. and EL-Mougy, S.A. (2000): Age-related changes in plasma testosterone concentrations and genital organs content of bulk and trace elements in the male dromedary. Anim. Reprod. 62: 297-307.

Arthur, G.H.; Rahim, A.T.A and AL-Hindi, A.S. (1985): Reproduction and Genital Diseases of the Camel. Bailliere and Tindall (Publ.), London, UK, pp 110120

Atiq, N.; Ullah, N.; Andrabi, S.M.H. and Akhter, S. (2011): Comparison of photometer with improved Neubauer Hemocytometer and makler counting chamber for sperm concentration measurement in cattle. Pak. Vet. J. 31(1): 83-84.

Axner, E.; Malmqvist, M.; Linde-Forsberg, C. and Rodriguez-Martinez, H. (1999): Regional histology of the ductus Epididymis in the domestic cat. J. Reprod. Develop. 45(2): 151-160.

Badr, M.R. and Abdel-Malak, M.G. (2010): In vitro fertilization and embryo production in dromedary camel using epididymal spermatozoa. Global Vet. 4(3): 271-276.

Bedford, J.M. (1975): Maturation, transport, and fate of spermatozoa in the epididymis. In: Handbook of Physiology. Vol. 5: Male Reproductive System. (Greep R.O., E.B. Astwood 
Eds.). American Physiology society, Washington, DC. Pp 303-317.

Beguelini, M.R.; Sergio, B.F.S.; Leme, F.L.J.; Taboga, S.R. and Versute, E.M. (2010): Morphological and morphometric characteristics of the epididymis in the Neotropical bats Eumops. glaucinus and Molossus molossus (Chiroptera: Molossidae). Chiroptera Neotropical 2: 769-779.

Bishop, M.W.H. and Walton, A. (1960): Spermatogenesis and the structure of mammalian spermatozoa. In: Marshall's Physiology of Reproduction, $3^{\text {rd }}$ ed., Vol. 1, pt. 2. (Parkes, A.S. Ed.) Longmans Green, London. Pp. 94-129.

Brown, B. (2000): A Review on Reproduction in South American Camelids. Anim. Reprod. Sci. J. 58 (3-4):169-195.

Crabo, B. (1965): Studies on the composition of epididymal content in bulls and boars. Acta Vet. Scand. Suppl. 5: 1-94.

Drury, R.A.B. and Wallington, E.A. (1976): Carleton's Histological Techniques. 4th edition. Oxford University Press, London. Pp. 21 - 71.

Ebada, S.M. (1994): Light and electron microscopic studies on the epididymis of the dromedary camel. M.V.Sc. Thesis, Faculty of Veterinary Medicine. Zagazig University.

El-Kon, I.I.; Heleil, B.A. and Mahmoud, S.A. (2011): Effect of age and season on the testicular sperm reserve and testosterone profile in camel (C. dromedaries) Anim. Reprod. 8: 68-72.

EL-Sisy, G.A., EL-Nattat, W.S. and ELSheshtawy, R.I., (2008): Effect of super oxide dismutase and catalase on viability of cryopreserved buffalo spermatozoa. Global Vet. 2(2): 56-61.

Glover, T.D. and Nicander, L. (1971): Some aspects of structure and function in the mammalian epididymis. J. Reprod. Fert., Suppl. 13: 39-50.

Goyal, H. (1985): Morphology of the bovine epididymis. Am. J. Anat. 172 (2): 155172.

Ibrahim, A.A.; Aliyu, J.; Hassan, A.M. and Salisu, N. (2012): Gonadal and extra gonadal sperm reserves of camel (Camelus dromedaries) in the semi-arid region of Nigeria. ARPN. J. Agri. Biol. Sci. 7 (5): 346-350.

Ibrahim, Z.H. and Singh, S.K. (2014): Histological and morphometric studies on the epididymis of the dromedary camel in relation to reproductive activity. Anim. Reprod Sci. 149: 212 217.

Junqueira, L. and Carneiro, J. (2003): Basic Histology: Text and Atlas. $10^{\text {th }}$ ed., McGraw Hill, Toronto, New York, London, Sydney, Melan, New Delhi, Lisbon, Madrid.

Karnovsky, A. (1965): A Formaldehydeglutaraldehyde fixative of high osmolarity for use in electron microscopy. Cell Biol. J. 27: 137-138.

Mahmud, M.A.; Onu, J.; Shehu, S.A.; Umaru, A.; Danmaigoro, A. and Atabo, M.S. (2015): Morphological studies on epididymis and vas deferens of one humped camel bull ( $C$. dromedarius), Uda Ram and Red Sokoto buck. Am. J. Biosci. Bioengine.5: 65-71.

Martini, F.; Ober, W.; Garrison, C.; Welch, K. and Hutchings, R (2001): Fundamentals of Anatomy \& Physiology. $5^{\text {th }}$ ed., Prentice Hall, Upper Saddle River.

Melo, M.I.V.; Henry, M. and Beker, A.R.C.L. (2005): Hypoosmotic test to predict viability of equine chilled semen in different extenders. Arq. Bras. Med. Vet. 57(6): 757-763. 
Mollenhauer, H. (1964): Plastic embedding mixture for use in electron microscopy. Stain Tech. 39: 111-114.

Mostafa, T.H.; Abd El-Salaam, A.M.; Elbadry, D.E. and Abear M. Anour (2014): Freezability and DNA integrity of dromedary camel spermatozoa in semen collected by artificial vagina and electro-ejaculator. Egyptian J. Anim. Prod. 51(2): 145-155.

Nickel, R.; Schummer, A. and Seiferle, E. (1979): The Viscera of the Domestic Mammals, 2nd Edition, Verlag Paul Parey Berlin, Hamburg, Pp: 81-85.

Novoa, C. (1970): Reproduction in Camelidae. Reprod. Fertil. 22: 3-20.

Olson, G.E. (1984): Changes in the sperm surface during maturation in the epididymis. In: Ultrastructure of Reproduction. Electron Microscopy in Biology and Medicine (Current Topics in Ultrastructural Research), Vol 2. Van Blerkom J. (Motta, P.M, Ed.), Springer, Boston, MA. Pp 97-109.

Osman, D.I. and Plöen, L. (1986): Fine structure of epididymal spermatozoa in the camel (C. dromedaries). Anim. Reprod. Sci. 10: 177-184.

Pineda, M.H. (1989): Male reproduction.

In: Veterinary Endocrinology and Reproduction. Fourth Edition. (Eds. LE McDonald and MH Pineda). Lea \& Febiger Philadelphia, London. Pp 261302.

Richardson, K.; Jarett, L. and Finke, E. (1960): Embedding in epoxy resins for ultrathin sectioning in electron microscopy. Stain Tech. 35: 313-323.

Rodríguez, H. and Bustos-Obregón, E. (1994): Seasonal and epididymal maturation of stallion spermatozoa. Andrologia 26: 161-164.

Ross, M.; Reith, E. and Romrell, L. (1989): Histology. A Text and Atlas. 2nd
Edition, Williams \& Wilkins, Philadelphia.

Scholkamy, T.H.; El-Badry, D.A. and Mahmoud, K.Gh.M. (2016):

Developmental competence of Dromedary camel oocytes fertilized in vitro by frozen-thawed ejaculated and epididymal spermatozoa. I. J.V. R. 17(4): 253-258.

Senger, P. (2006): The Organization and Function of the Male Reproductive Tract. In: Pathways to Pregnancy and Parturition. $2^{\text {nd }}$ ed. (Senger P.L., Ed.), Cadmus Professional Communications Science Press Division, Ephrata.

Skidmore, L. (2000): Anatomy of the camel reproductive tract. In: Recent advances in camelid reproduction. International Veterinary Information Service, Ithaca, New York, USA.

SPSS (2017): Statistical Package for Social Science (IBM- SPSS) Program Ver.23 for windows, SPSS Inc., USA.

Sutovsky, P; Moreno, R.; Ramalho-Santos, J.; Dominko, T. Thompson, W.E.; and Schatten, G. (2001). A putative, ubiquitin-dependent mechanism for the recognition and elimination of defective spermatozoa in the mammalian epididymis. J. Cell Sci. 114: 1665-1675.

Turner, T. (1984): Resorption versus Secretion in the Rat Epididymis. J. Reprod. Fert. 72(2): 509-514

Yamamoto, M. and Turner, T. (1991): Epididymis, sperm maturation, and capacitation. in: infertility in male. $2^{\text {nd }}$ ed. Chapter 6, Mosby Year Book, St. Louis, Balti-more, Boston, Chicago, London, Philadelphia, Sydney, Toronto. Pp.191.

Yu, 1. and Leibo, S.P. (2002): Recovery of motile, membrane-intact spermatozoa from canine epididymis stored for 8 days at 4 degrees $C$. Theriogenology 57(3): 1179-1190. 
Histomorphometry of Dromedary Camel Epididymis and its Correlation with Spermatozoa Characteristics during their Epididymal Transport

Zayed, A.E.; Aly, K.; Ibrahim, I.A. and Abd

El-Maksoud,

F.M.,

(2012):

Morphological studies on the epididymal duct of the one-humped camel (Camelus dromedaries). Open J. Vet. Med. 2: 245-254. 